\title{
ANALISA KEPUTUSAN PEMBELIAN DETERJEN SOKLIN SMART DITINJAU DARI KELOMPOK REFERENSI, KUALITAS PRODUK DAN PROMOSI DI KABUPATEN WONOGIRI
}

\author{
Budi Rahayu, Djumali, Sudarwati \\ Universitas Islam Batik Surakarta, Indonesia \\ Email : srilestariedi@yahoo.com
}

\begin{abstract}
The research aims to find out and describe the influence of either simultaneously or partial reference groups, product quality and promotion to purchasing decision for Soklin Smart Detergent in Wonogiri District. This research using quantitative descriptive research. The population was all consumer Soklin Smart Detergent in Wonogiri District unknown number. The number of samples was determined with the formula Sarwono and the result 100 respondents. Sampling method using accidental sampling. The questionnaire used for data retrieval. Data analysis technique used was statistic analysis. This $F$ test results the reference groups, product quality and promotion simultaneously and significant effect to purchasing decision for Soklin Smart Detergent in Wonogiri District. The t-test results showed that the reference groups influential positive and significant effect against to purchasing decision for Soklin Smart Detergent in Wonogiri District. Product quality influential positive and significant effect against to purchasing decision for Soklin Smart Detergent in Wonogiri District. Promotion influential positive and significantly to purchasing decision for Soklin Smart Detergent in Wonogiri District. The results of the determination of the coefficient indicates the reference groups, product quality and promotion have influence of 57,2\% the purchasing decision for Soklin Smart Detergent in Wonogiri District. The most dominant influence to purchasing decision for Soklin Smart Detergent in Wonogiri District is product quality because it has the most $t_{\text {value }}$ is 6,654.
\end{abstract}

Keywords: Purchasing Decision, Reference Groups, Product Quality, Promotion

\section{PENDAHULUAN}

Bervariasinya saat proses pengambilan keputusan, ada yang kompleks maupun sederhana. Pada proses pengambilan keputusan ini tidak berkahir pada saat keputusan pembelian saja akan tetapi diikuti oleh perilaku konsumen pasca pembelian. Hal ini akan mempengaruhi puas atau tidaknya konsumen dalam menggunakan produk yang dibelinya. Apabila kepuasan yang didapatkan konsumen maka akan cenderung untuk memutuskan membeli kembali produk tersebut dan akan mereferensikan kepada orang lain tentang kebaikan produk.

Sikap konsumen dapat dipengaruhi oleh kelompok referensi. Dalam keputusan pembelian suatu produk, saudara, tetangga atau rekan kerja dapat dijadikan dasar pertimbangan. Berbagai persepsi kelompok referensi yang pernah melakukan pembelian produk dan didengarkan oleh konsumen akan sangat mempengaruhi seorang konsumen dalam melakukan keputusan pembelian. Persepsi tersebut bisa berbentuk ajakan, bujukan maupun saran.

Selain kelompok referensi, kualitas produk juga dapat mempengaruhi keputusan konsumen dalam membeli sebuah produk. Kualitas produk menjadi konsep yang paling penting dalam membuat atau memciptakan produk. Konsumen dapat menerima suatu produk apabila sesuai dengan keinginan dan kebutuhan. Maka dari itu, perusahaan harus jeli dalam melihat setiap peluang yang ada yang berkaitan dengan kualitas produk yang diinginkan dan dibutuhkan oleh konsumen. Selain itu, manfaatkan yang didapatkan dari sebuah produk dapat mencerminkan kualitasnya.

Promosi juga menjadi salah satu faktor yang dapat mempengaruhi konsumen dalam memutuskan membeli suatu produk. Salah satuhal yang dilakukan perusahaan dalam memasarkan produknya yaitu dengan melakukan promosi. Adanya promosi, yang sebelumnya orang tidak tahu mengenai suatu produk menjadi tahu, kemudian tertarik untuk mencoba yang pada akhirnya memakai produk tersebut. Perusahaan harus melakukan penelitian tentang produknya sebelum mendapatkan konsumen yang mau membeli 
produknya. promosi yang dilakukan perusahaan haruslah terarah dan kreatif untuk dapat meningkatkan keputusan pembelian konsumen.

Produk PT.Wingsfood salah satunya Deterjen Soklin Smart. Adanya permintaan produk deterjen yang terus mengalami peningkatan membuat persaingan antar perusahaan sejenis menjadi semakin ketat. Adanya masyarakat yang lebih cenderung menggunakan produk Deterjen Soklin Smart padahal di pasaran banyak dijual deterjen berbagai merek maupun manfaat yang diperoleh. tentunya ada faktor yang sangat dominan dalam mempengaruhi konsumen tersebut tetap memilih Deterjen Soklin Smart. Misalnya adanya promosi penjualan langsung yang didapatkan konsumen ketika membeli Deterjen Soklin Smart berupa piring keramik. Selain itu Deterjen Soklin Smart juga memiliki kualitas produk yang mampu menghilangkan noda pakaian secara menyeluruh. Dari uraian di atas penulis berpendapat layak untuk melakukan penelitian dengan judul : Analisa Keputusan Pembelian Deterjen Soklin Smart ditinjau dari Kelompok Referensi, Kualitas Produk dan Promosi di Kabupaten Wonogiri.

\section{LANDASAN TEORI}

Schiffman dan Kanuk (2013: 82) menjelaskan keputusan pembelian adalah aktivitas yang dilakukan oleh konsumen dalam membeli suatu produk. Kotler dan Keller (2015:170) mendefinisikan kelompok referensi merupakan seorang konsumen atau kelompok yang sudah menggunakan suatu produk yang dapat memberikan pengaruh terhadap calon konsumen lainnya. Simamora (2014: 8) mendefinisikan kualitas produk yaitu keunggulan yang dimiliki produk untuk mampu menarik konsumen dalam melakukan pembelian. Swastha (2014: 349) menjelaskan promosi merupakan salah satu proses pemasaran yang dilakukan perusahaan untuk mengarahkan konsumen dalam melakukan pembelian suatu produk. Kerangka pemikiran pada penelitian ini adalah:

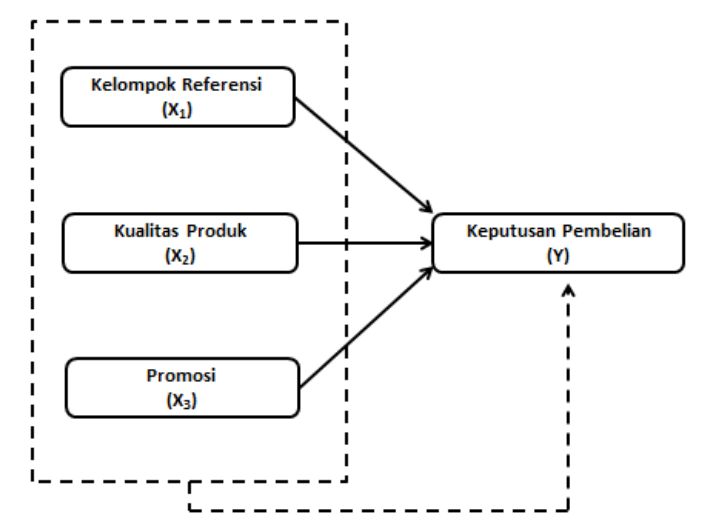

Gambar 2.1 Kerangka Berpikir

\section{METODOLOGI PENELITIAN}

Penelitian ini menggunakan penelitian kuantitatif. Tempat penelitian di Kabupaten Wonogiri. Populasi penelitian ini adalah semua konsumen Deterjen Soklin Smart di Kabupaten Wonogiri yang sifatnya tidak diketahui jumlahnya. Dalam menentukan jumlah sampel digunakan rumus yang di kemukakan oleh Sarwono (2013: 109) sebagai: 


$$
\mathrm{n}=\frac{\mathrm{Z}^{2} \cdot \mathrm{p} \cdot \mathrm{q}}{\mathrm{d}^{2}}
$$

Keterangan:

$\mathrm{n}=$ jumlah sampel.

$Z=$ harga standar normal $(1,976)$

$\mathrm{p}=$ estimator proporsi populasi $(0,5)$

$\mathrm{d}=$ interval/penyimpangan $(0,10)$

$\mathrm{q}=1-\mathrm{p}$

Jadi besar sampel dapat di hitung sebagai berikut:

$$
\mathrm{n}=\frac{(1,976)^{2}(0,5)(0,5)}{(0,10)^{2}}=97,6
$$

Dari hasil perhitungan maka dibulatkan menjadi 100 responden yang dijadikan sampel. Teknik sampling menggunakan metode accidental sampling, peneliti mengambil sampel siapa saja yang berada di tempat atau kebetulan bertemu dan dipandang cocok sebagai sumber data (Sugiyono, 2014: 77). Kuesioner digunakan untuk pengambilan data. Regresi linier berganda sebagai metode untuk menganalisis data.

\section{PEMBAHASAN}

4.1 Uji asumsi klasik

a. Hasil uji normalitas

Menguji normalitas digunakan alat analisis Kolmogorov-Smirnov, hasilnya adalah: Tabel 4.1

Hasil Uji Normalitas One-Sample Kolmogorov-Smirnov Test

\begin{tabular}{llc}
\hline \multicolumn{2}{c}{ One-Sample Kolmogorov-Smirnov Test } \\
\hline$N$ & $\begin{array}{c}\text { Unstandardized } \\
\text { Residual }\end{array}$ \\
\hline Normal Parametersa, ${ }^{a}$ bean & 100 \\
& Std. Deviation & .0000000 \\
Most Extreme & Absolute & .83344064 \\
Differences & Positive & .080 \\
Kolmogorov-Smirnov $Z$ & Negative & -.084 \\
Asymp. Sig. (2-tailed) & & .842 \\
& & .477 \\
\hline
\end{tabular}

Nilai Asymp. Sig. $(0,477)$ lebih besar dari 0,05. Artinya persamaan regresi memiliki sebaran data yang normal.

b. Hasil uji multikolinearitas

Hasil yang di dapatkan dalam uji multikolinearitas adalah:

Tabel 4.2

Uji Multikolinearitas

\begin{tabular}{lll}
\multicolumn{3}{c}{$\begin{array}{c}\text { Uji Multikolinearitas } \\
\text { Coefficients }^{a}\end{array}$} \\
\hline Model & \multicolumn{2}{c}{ Collinearity } \\
& Statistics \\
& Tolerance $^{\text {VIF }}$ \\
\hline 1 (Constant) & & \\
Kelompok Referensi & .734 & 1.362 \\
Kualitas Produk & .738 & 1.354 \\
Promosi & .800 & 1.250 \\
\hline
\end{tabular}

Berdasarkan tabel di atas menunjukkan hasil dari pengujian multikolinearitas, nilai VIF kelompok referensi 1,362 , kualitas produk 1,354 , promosi 1,250 yang semuanya $<10$. Jadi tidak terdapat adanya multikolinieritas. 
c. Hasil uji heteroskedastisitas

Hasil yang di dapatkan dalam uji heteroskedastisitas adalah:

Tabel 4.3

Hasil Uji Heteroskedastisitas Coefficients $^{a}$

\begin{tabular}{llr}
\hline Model & Sig. \\
\hline 1 & (Constant) & .098 \\
& Kelompok Referensi & .467 \\
& Kualitas Produk & .150 \\
& Promosi & .975 \\
\hline
\end{tabular}

Berdasarkan tabel di atas menunjukkan nilai sig. kelompok referensi 0,467 $>0,05$, nilai sig. kualitas produk $0,150>0,05$ dan nilai sig. Promosi $0,975>0,05$. Model regresi ini tidak terjadi adanya heteroskedastisitas.

4.2 Hasil analisis data

a. Regresi linier berganda

Nilai a dan $b_{1}, b_{2}, b_{3}$ dalam uji regresi linier berganda adalah:

Tabel 4.4

Analisis Regresi Linier Berganda

\begin{tabular}{llrr}
\multicolumn{3}{c}{ Coefficients $^{a}$} \\
\hline & \multicolumn{2}{c}{$\begin{array}{c}\text { Unstandardized } \\
\text { Coefficients }\end{array}$} \\
& B & Std. Error \\
\hline 1 (Constant) & .292 & 1.794 \\
& Kelompok Referensi & .245 & .085 \\
Kualitas Produk & .520 & .078 \\
Promosi & .229 & .077 \\
\hline
\end{tabular}

Berdasarkan tabel di atas diperoleh persamaannya adalah:

$Y=0,292+0,245 X_{R}+0,520 X_{K}+0,229 X_{P}+e$

b. Uji F

Perhitungan nilai $\mathrm{F}_{\text {hitung }}$ adalah:

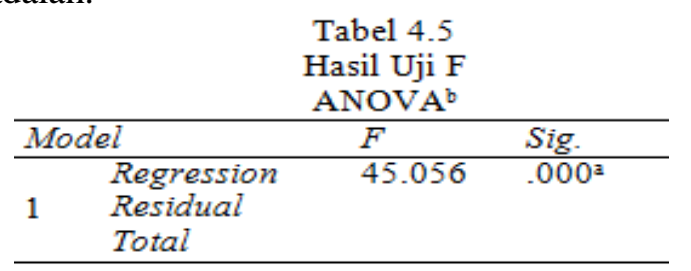

Hasil uji serempak dengan program SPSS, diketahui besarnya nilai $F_{\text {hitung }}>F_{\text {tabel }}(45,056)>$ $(2,70)$ dengan signifikan $0,000<0,05$, Ho ditolak artinya kelompok referensi, kualitas produk dan promosi secara signifikan dan simultan mempengaruhi keputusan pembelian Deterjen Soklin Smart di Kabupaten Wonogiri. 
c. Uji t

Perhitungan uji t adalah:

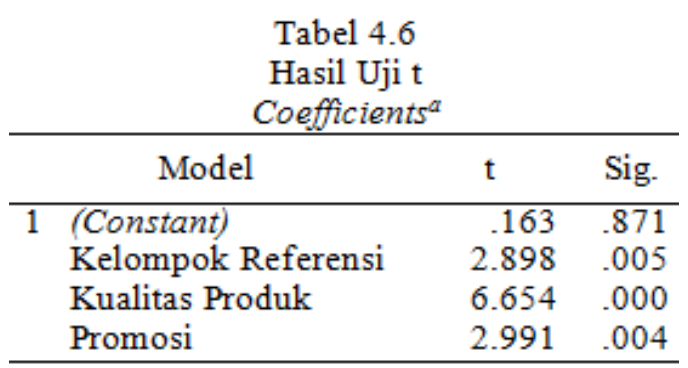

1) Pada variabel kelompok referensi hasil nilai $t_{\text {hitung }}(2,898)>t_{\text {tabel }}(1,985)$ dengan signifikan $0,005<0,05$, artinya $H_{o}$ ditolak, secara signifikan kelompok referensi mempengaruhi keputusan pembelian Deterjen Soklin Smart di Kabupaten Wonogiri.

2) Pada variabel kualitas produk hasil nilai $t_{\text {hitung }}(6,654)>t_{\text {tabel }}(1,985)$ dengan signifikan $0,000<$ 0,05 , artinya $\mathrm{H}_{\mathrm{o}}$ ditolak, secara signifikan kualitas produk mempengaruhi keputusan pembelian Deterjen Soklin Smart di Kabupaten Wonogiri.

3) Pada variabel promosi hasil nilai $t_{\text {hitung }}(2,991)>t_{\text {tabel }}(1,985)$ dengan signifikan $0,004<0,05$, artinya $\mathrm{H}_{\mathrm{o}}$ ditolak, secara signifikan promosi mempengaruhi keputusan pembelian Deterjen Soklin Smart di Kabupaten Wonogiri.

d. Koefisien determinasi

Perhitungan nilai koefisien determinasi adalah:

Tabel 4.7

Hasil Koefisien Determinasi

Model Summary

\begin{tabular}{ccc}
\hline$R$ & R Square & Adjusted R Square \\
\hline $765^{\mathrm{a}}$ & .585 & .572 \\
\hline
\end{tabular}

Nilai Adjusted $R^{2}$ sebesar 0,572. Artinya 57,2\% keputusan pembelian dipengaruhi oleh kelompok referensi, kualitas produk dan promosi. Sedangkan 42,8\% (100\%-57,2\%) adalah variabel lain di luar dari variabel penelitian, seperti harga, distribusi dan lain-lain.

\subsection{Pembahasan}

a. Berdasarkan hasil uji $\mathrm{F}$, kelompok referensi, kualitas produk dan promosi secara signifikan dan simultan mempengaruhi keputusan pembelian Deterjen Soklin Smart di Kabupaten Wonogiri. Hal ini didasarkan pada hasil penelitian yang dapat dilihat dari $\mathrm{F}_{\text {hitung }}$ sebesar 45,056 dan signifikansinya < $5 \%$ yaitu 0,000 . Hasil tersebut membuktikan bahwa semakin tinggi kelompok referensi, kualitas produk dan promosi maka pada keputusan pembelian Deterjen Soklin Smart di Kabupaten Wonogiri akan mengalami peningkatan secara nyata.

b. Berdasarkan analisis uji $\mathrm{t}$ diperoleh kelompok referensi mempengaruhi secara signifikan pada keputusan pembelian Deterjen Soklin Smart di Kabupaten Wonogiri. Hal ini didasarkan pada hasil $\mathrm{t}_{\text {hitung }}$ yaitu sebesar 2,898, koefisien regresi bernilai 0,245 dan signifikansinya $<5 \%$ yaitu 0,005 . Artinya apabila pola kelompok referensi yang ada semakin tinggi, maka keputusan pembelian Deterjen Soklin Smart di Kabupaten Wonogiri akan meningkat. Informasi yang diperoleh dari kelompok referensi dapat membantu konsumen dalam menentukan pilihan pengambilan keputusan yang berkaitan dengan produk Deterjen Soklin Smart. Hasil ini mendukung penelitian Debora, Sulistyowati dan Musfar (2014) kelompok referensi mempengaruhi secara signifikan pada keputusan pembelian.

c. Berdasarkan analisis uji $\mathrm{t}$ diperoleh kualitas produk mempengaruhi secara signifikan pada keputusan pembelian Deterjen Soklin Smart di Kabupaten Wonogiri. Hal ini didasarkan pada hasil

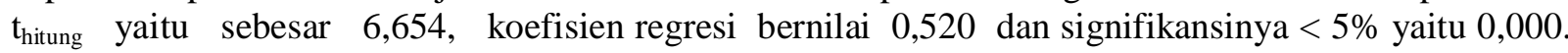
Artinya apabila pola kualitas produk yang ada semakin tinggi, maka keputusan pembelian Deterjen 
Soklin Smart di Kabupaten Wonogiri akan meningkat. Kualitas produk yang diberikan oleh Deterjen Soklin Smart dapat memberikan kepuasan bagi konsumen. Hasil ini mendukung penelitian Amron (2018) kualitas produk mempengaruhi secara signifikan pada keputusan pembelian.

d. Berdasarkan analisis uji $\mathrm{t}$ diperoleh promosi mempengaruhi secara signifikan pada keputusan pembelian Deterjen Soklin Smart di Kabupaten Wonogiri. Hal ini didasarkan pada hasil thitung yaitu sebesar 2,991, koefisien regresi bernilai 0,229 dan signifikansinya $<5 \%$ yaitu 0,004. Artinya apabila pola promosi yang ada semakin tinggi, maka keputusan pembelian Deterjen Soklin Smart di Kabupaten Wonogiri akan meningkat. Adanya promosi penjualan yang diberikan perusahan melalui pembelian produk Deterjen Soklin Smart akan mendapatkan piring keramik, maka dalam hal ini akan menarik konsumen untuk melakukan proses pembelian. Hasil ini mendukung penelitian Khanfar (2016) promosi mempengaruhi secara signifikan pada keputusan pembelian.

\section{KESIMPULAN}

Kesimpulan :

a. Kelompok referensi, kualitas produk dan promosi mempengaruhi secara signifikan dan simultan pada keputusan pembelian Deterjen Soklin Smart di Kabupaten Wonogiri.

b. Kelompok referensi mempengaruhi secara signifikan pada keputusan pembelian Deterjen Soklin Smart di Kabupaten Wonogiri.

c. Kualitas produk mempengaruhi secara signifikan pada keputusan pembelian Deterjen Soklin Smart di Kabupaten Wonogiri.

d. Promosi mempengaruhi secara signifikan pada keputusan pembelian Deterjen Soklin Smart di Kabupaten Wonogiri.

Saran

a. untuk membangun kepercayaan konsumen terhadap Deterjen Soklin Smart.

b. Hendaknya perusahaan Wings Surya dapat melakukan promosi yang lebih menarik lagi guna meningkatkan keputusan pembelian produk Deterjen Soklin Smart. 


\section{REFERENSI}

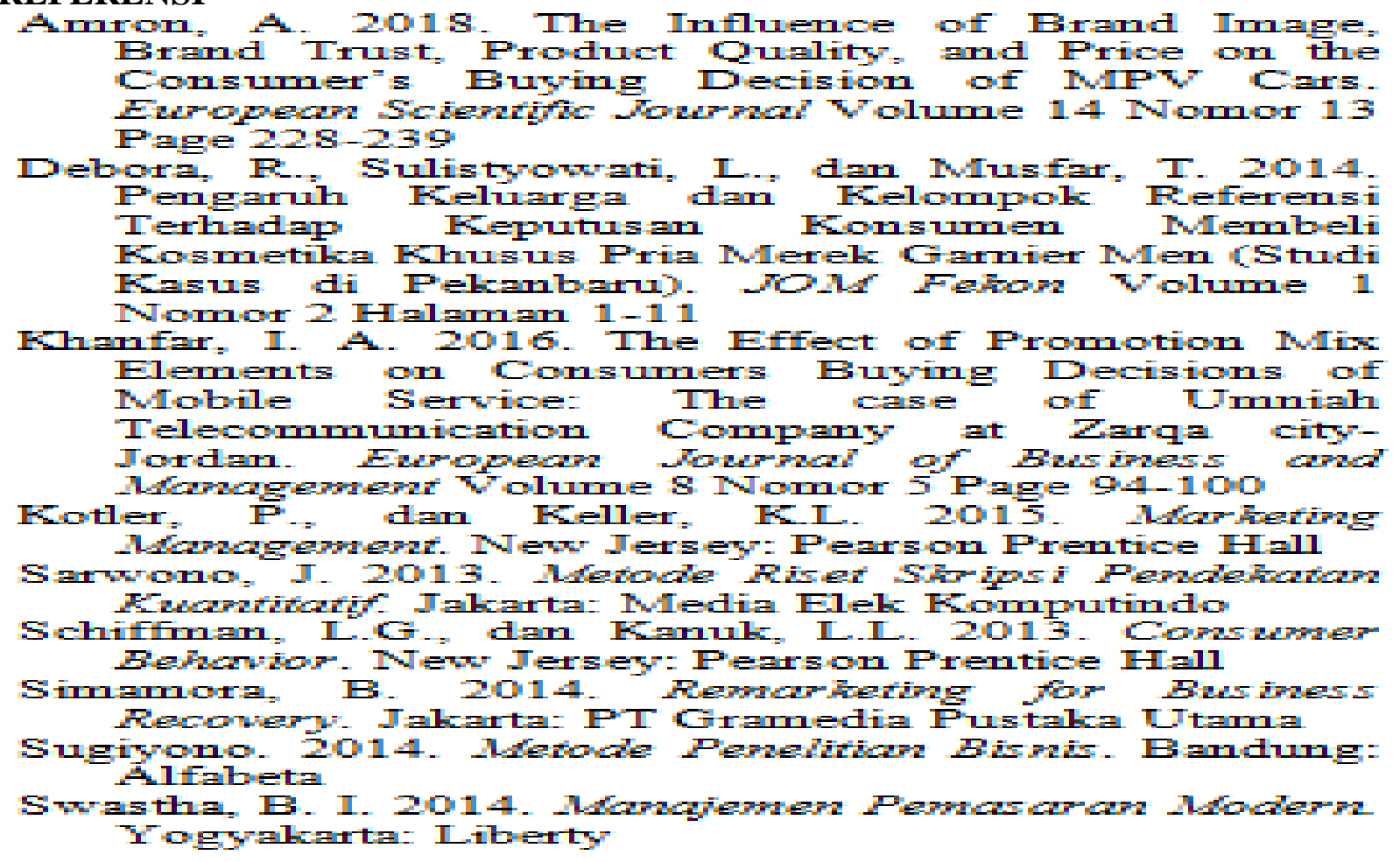

